\title{
A New Megastigmane Glucoside and Other Constituents from Desmodium gangeticum
}

\author{
Hau Viet Dang, ${ }^{1}$ Giang Hoang Do, ${ }^{1}$ Phuong Thi Ngo, ${ }^{2}$ Tien Dat Nguyen $\mathbb{D}^{1},{ }^{1}$ \\ and Ha Minh Le $\mathbb{D D}^{2}$ \\ ${ }^{1}$ Center for Research and Technology Transfer, Vietnam Academy of Science and Technology (VAST), 18-Hoang Quoc Viet, \\ Cau Giay, Hanoi, Vietnam \\ ${ }^{2}$ Institute of Natural Products Chemistry, Vietnam Academy of Science and Technology(VAST), 18-Hoang Quoc Viet, Cau Giay, \\ Hanoi, Vietnam
}

Correspondence should be addressed to Tien Dat Nguyen; ngtiend@imbc.vast.vn and Ha Minh Le; leminhha.inpc@gmail.com

Received 13 August 2020; Revised 25 September 2020; Accepted 14 October 2020; Published 4 November 2020

Academic Editor: Alessandro Arcovito

Copyright $\odot 2020$ Hau Viet Dang et al. This is an open access article distributed under the Creative Commons Attribution License, which permits unrestricted use, distribution, and reproduction in any medium, provided the original work is properly cited.

A new megastigmane glycoside, gangeticoside (1), and three known compounds leonuriside A (2), methyl benzoate 2-O- $\beta$-Dglucopyranoside (3), and tortoside A (4) were isolated from the aerial part of Desmodium gangeticum. Their structures were determined by $1 \mathrm{D}$ and 2D NMR spectra. The isolated compounds were evaluated for their inhibitory effect on NO production in LPS-stimulated RAW264.7 cells. Among them, compounds 1, 2, and 3 exhibited strong effect with the IC $_{50}$ values of 22.3, 15.6, $7.3 \mu \mathrm{M}$, respectively.

\section{Introduction}

Desmodium gangeticum (L.) DC. is a woody perennial herb plant, which distributed wildly in the mountainous area in Vietnam, or several regions in Asia and Africa [1, 2]. D. gangeticum has been used for the treatment of asthma, stomatitis, arthritis, eczema, or some other diseases [1]. Previous studies proved the contents of flavonoids, alkaloids, and sterols in D. gangeticum with hepatoprotective, antiinflammatory, antileishmanial, immunomodulatory, cardioprotective, antinociceptive wound healing, antidiabetic, and antiulcer activities [3-6]. Nitric oxide (NO) has been known to involve in the regulation of various physiological processes in mammals and the overproduction of $\mathrm{NO}$ is responsible for the pathological development of inflammation, cancer, and diabetes $[7,8]$. Therefore, inhibitors of NO production have potential therapeutic value as anti-inflammatory agents [9]. In this study, we reported the isolation of a new megastigmane glycoside $\mathbf{1}$ and three known compounds from D. gangeticum (Figure 1). The isolated compounds were evaluated for their inhibition of nitric oxide (NO) production in LPS-stimulated RAW264.7 cells.

\section{Materials and Methods}

2.1. Plant Materials. D. gangeticum was collected in $\mathrm{Me}$ Linh, Vinh Phuc Province, in June 2017, and identified by Dr Bui Van Thanh, Institute of Ecology and Biological Resources (IEBR). Voucher specimens (No TL-DG200617) have been deposited at the Pharmaceutical Chemistry Laboratory, Institute of Natural Product Chemistry, VAST.

2.2. General Experimental Procedures. NMR experiments were performed on a Bruker AM500 FT-NMR spectrometer with tetramethylsilane (TMS) as an internal standard. The optical rotations were read on a JASCO P-2000 digital polarimeter. High-resolution mass spectra (ESI, positive mode) were obtained with a Thermo LTQ Orbitrap XL mass spectrometer. Thin-layer chromatography (TLC) was performed on precoated silica gel 60 F254 plates (Merck, Germany), and spots were detected under UV illumination at $254 \mathrm{~nm}$ and spraying with $\mathrm{H}_{2} \mathrm{SO}_{4} 10 \%$ reagent followed by heating. Column chromatography (CC) was carried out using D101 resin (0.3-1.5 mm, Extrepure, China), silica gel 


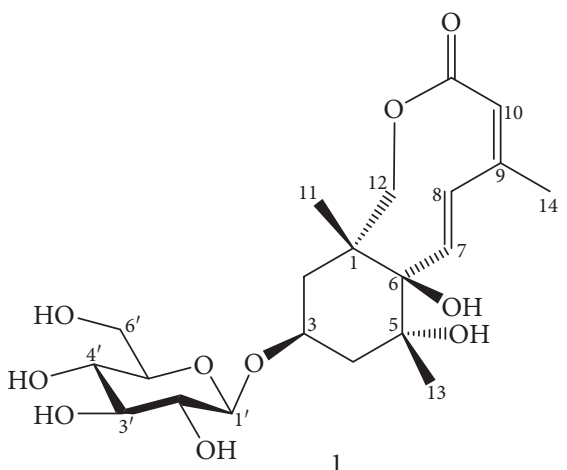

(a)

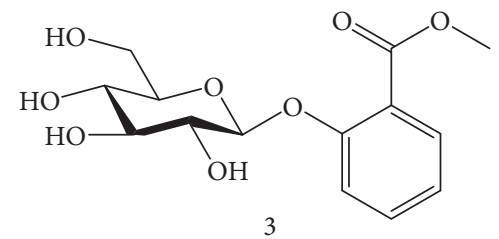

(c)

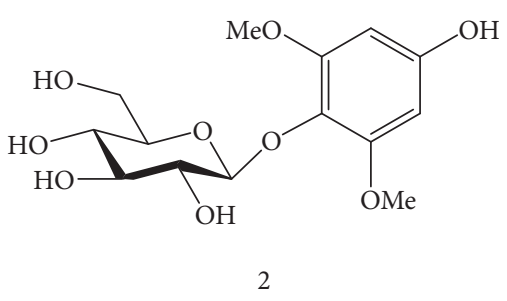

(b)

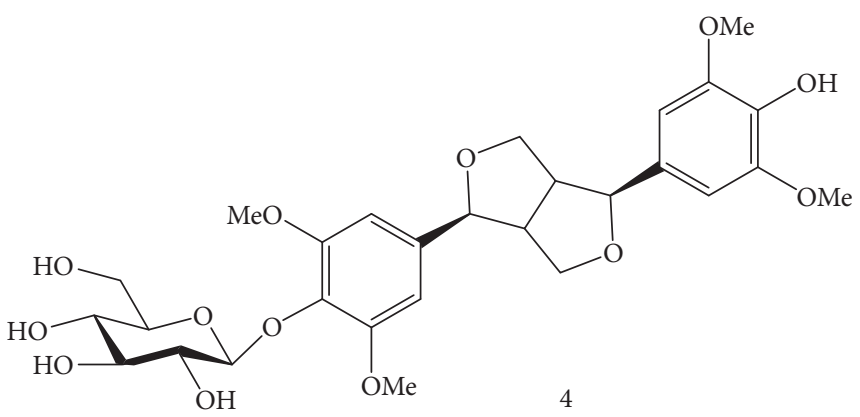

(d)

Figure 1: The structure of compounds isolated from Desmodium gangeticum.

60 (70-230 mesh, Merck, Germany), or YMC RP-C18 resin (150 $\mu \mathrm{m}, \mathrm{YMC}$, Japan). The sugar was analysed by an Agilent 1260 Series Single Quadrupole LC/MS Systems.

2.3. Extractions and Isolation. The air-dried powdered aerial parts of Desmodium gangeticum were extracted with methanol $(6 \mathrm{~L} \times 3$ times $)$ at room temperature in 24 hours. The combined extracts were concentrated to obtain a methanol $(\mathrm{MeOH})$ crude residue $(180 \mathrm{~g})$, which was suspended in water and then successively partitioned with ethyl acetate. Evaporation of solvents under reduced pressure gave ethyl acetate residues $(87.5 \mathrm{~g})$. The water layer was adsorbed on a Diaion HP-20 column and then eluted with water, methanol 50\%, and $100 \%$ to collect W, M50, and M100 fractions, respectively. Fraction M100 was subjected to a silica gel chromatography column with gradient mixtures of $\mathrm{CH}_{2} \mathrm{Cl}_{2}-\mathrm{MeOH}(1 / 0-0 / 1, \mathrm{v} / \mathrm{v})$ to yield seven fractions, B1B7. Fraction B2 was separated on a Sephadex LH-20 column eluted with methanol $50 \%$ to obtain two subfraction B2.1 and B2.2. The fraction B2.1 was purified on a YMC-C18 chromatography column eluted with methanol $67 \%$ to yield compound 1 (5.2 mg). The fraction B2.2 was isolated on a silica gel chromatography column with $\mathrm{CH}_{2} \mathrm{Cl}_{2}-\mathrm{MeOH}$ (6/ $1, \mathrm{v} / \mathrm{v})$ elution to obtain compound 2 (10.3 mg). Compound $3(6.1 \mathrm{mg})$ was separated from the fraction B4 using a YMCC18 chromatography column eluted with methanol $50 \%$. Fraction B6 was isolated on a Sephadex LH-20 column eluted with methanol 60\%, followed by a YMC RP-C18 column eluted with methanol $50 \%$ to collect compound 4 (6.6 mg).
Gangeticoside (1): white solid; $(\alpha)_{\mathrm{D}}{ }^{24}=-8.5^{\circ}$ (c 0.1 , $\mathrm{CH}_{3} \mathrm{OH}$ ); ${ }^{1} \mathrm{H}$ NMR (500 MHz, $\left.\mathrm{CD}_{3} \mathrm{OD}\right): \delta 0.94(3 \mathrm{H}$, br s, H-8 ${ }^{\prime}$ ), 1.17 (3H, br s, H-7 $), 2.02$ (3H, br s, H-6), 1.83 (2H, m, H-2' a, $\left.4^{\prime} \mathrm{a}\right), 1.98\left(1 \mathrm{H}, \mathrm{dd}, J=14.0,6.5 \mathrm{~Hz}, \mathrm{H}-2^{\prime} \mathrm{b}\right), 2.20(1 \mathrm{H}$, $\left.\mathrm{dd}, J=13.5,7.0 \mathrm{~Hz}, \mathrm{H}-4^{\prime} \mathrm{b}\right), 3.16(1 \mathrm{H}, \mathrm{dd}, J=9.0,8.0 \mathrm{~Hz}$, $\left.\mathrm{H}-2^{\prime \prime}\right), 3.35\left(3 \mathrm{H}, \mathrm{m}, \mathrm{H}-3^{\prime \prime}, 4^{\prime \prime}, 5^{\prime \prime}\right), 3.68(1 \mathrm{H}, \mathrm{dd}, J=11.5$, $\left.5.5 \mathrm{~Hz}, \mathrm{H}-6^{\prime \prime} \mathrm{a}\right), 3.77\left(1 \mathrm{H}, \mathrm{d}, J=7.5 \mathrm{~Hz}, \mathrm{H}-9^{\prime} \mathrm{a}\right), 3.82(1 \mathrm{H}, \mathrm{d}$, $\left.J=7.5 \mathrm{~Hz}, \mathrm{H}-9^{\prime} \mathrm{b}\right), 3.88\left(1 \mathrm{H}, \mathrm{d}, J=11.5 \mathrm{~Hz}, \mathrm{H}-6^{\prime \prime} \mathrm{b}\right), 4.27(1 \mathrm{H}$, m, H-3') $4.38\left(1 \mathrm{H}, \mathrm{d}, J=8.0 \mathrm{~Hz}, \mathrm{H}-1^{\prime \prime}\right), 5.85(1 \mathrm{H}, \mathrm{s}, \mathrm{H}-2)$, $6.35(1 \mathrm{H}, \mathrm{d}, J=15.5 \mathrm{~Hz}, \mathrm{H}-5), 7.89(1 \mathrm{H}, \mathrm{d}, J=15.5 \mathrm{~Hz}, \mathrm{H}-4)$. ${ }^{13} \mathrm{C}$ NMR (125 MHz, CD $\left.3 \mathrm{OD}\right): \delta 167.9(\mathrm{C}-1), 125.7(\mathrm{C}-3)$, 144.5 (C-3), 132.7 (C-4), 131.7 (C-5), 20.7 (C-6), $49.8\left(\mathrm{C}-1^{\prime}\right)$, $42.8\left(\mathrm{C}-2^{\prime}, 4^{\prime}\right), 73.9\left(\mathrm{C}-3^{\prime}\right), 87.6\left({\mathrm{C}-5^{\prime}}^{\prime}\right), 83.2\left(\mathrm{C}-6^{\prime}\right), 19.7(\mathrm{C}-$ $\left.7^{\prime}\right), 16.3\left(\mathrm{C}-8^{\prime}\right), 77.9\left(\mathrm{C}-9^{\prime}\right), 103.1\left(\mathrm{C}-1^{\prime \prime}\right), 75.1\left(\mathrm{C}-2^{\prime \prime}\right), 78.0$ $\left(\mathrm{C}-3^{\prime \prime}\right), 71.6\left(\mathrm{C}-4^{\prime \prime}\right), 77.9\left(\mathrm{C}-5^{\prime \prime}\right), 62.7\left(\mathrm{C}-6^{\prime \prime}\right)$. HR-ESI-MS: $m / z 467.1896[\mathrm{M}+\mathrm{Na}]^{+}$(calcd. 467.1893 for $\mathrm{C}_{21} \mathrm{H}_{32} \mathrm{NaO}_{10}$ ).

2.4. Acid Hydrolysis and Sugar Identification. Compound 1 $(1 \mathrm{mg})$ was heated in $1 \mathrm{~N} \mathrm{HCl}(500 \mu \mathrm{L})$ at $80^{\circ} \mathrm{C}$ for $2 \mathrm{~h}$, then the solution was extracted with ethyl acetate $(1 \mathrm{ml} \times 3)$. The aqueous layer was neutralized with $\mathrm{NH}_{4} \mathrm{OH}$ and then dried under reduced pressure. The obtained residue was redissolved in $150 \mu \mathrm{L}$ pyridine containing $10 \mu \mathrm{mol}$ of L-cysteine methyl ester and heated at $80^{\circ} \mathrm{C}$ for $1 \mathrm{~h}$. $6 \mu \mathrm{lo}$-tolyl isothiocyantate was added, and the solution was heated for another hour. The reaction solution was then analyzed by HPLC using Cosmosil 5C18-MS-II column $(4.6 \times 150 \mathrm{~mm})$, mobile phase of $20 \%$ acetonitrile in $0.2 \%$ TFA water, UV detection at $254 \mathrm{~nm}$. The sugars were identified as D-glucose $\left(t_{\mathrm{R}} 9.05 \mathrm{~min}\right)$. 


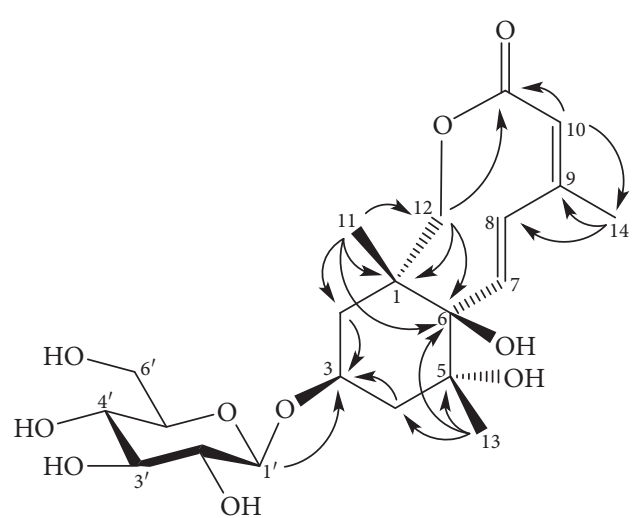

(a)

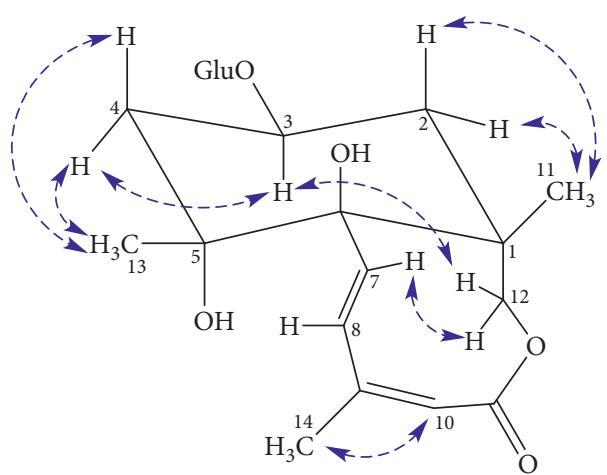

(b)

Figure 2: Key HMBC, and NOESY correlations of the new compound 1.

2.5. Assay for Inhibition of NO Production. The anti-inflammatory effects of the isolated compounds were evaluated via the inhibition of NO production in LPS-stimulated RAW264.7 cells [10]. Briefly, RAW264.7 cells were seeded in 96-well plates at $2 \times 105$ cells/well and incubated for $24 \mathrm{~h}$. The plate were pretreated with various concentrations of test samples for $30 \mathrm{~min}$ and then incubated for another $24 \mathrm{~h}$ with or without $1 \mu \mathrm{g} / \mathrm{mL}$ LPS. As a parameter of NO synthesis, nitrite concentration in the culture supernatant was measured by the Griess method. $100 \mu \mathrm{L}$ of the culture supernatant was transferred to other 96-well plate and $100 \mu \mathrm{L}$ of Griess reagent were added. The absorbance of the reaction solution was read at $570 \mathrm{~nm}$ with a microplate reader. The remaining cell solutions in cultured 96-well plates were used to evaluate cell viability by 3-(4,5-dimethylthiazole-2-yl)2,5-diphenyl tetrazolium bromide (MTT) assay. Cardamonin was used as a positive control.

\section{Results and Discussion}

Compound 1 was obtained as a colorless solid. Its HRESIMS (Figure S1) showed the peak at $\mathrm{m} / z 467.1896[\mathrm{M}+\mathrm{Na}]^{+}$ corresponding to the molecular formula $\mathrm{C}_{21} \mathrm{H}_{32} \mathrm{O}_{10}$. The ${ }^{1} \mathrm{H}$ NMR spectrum of 1 (Figure S2) showed signals for a transdouble-bond at $\delta_{\mathrm{H}} 6.35(1 \mathrm{H}, \mathrm{d}, J=15.5 \mathrm{~Hz}, \mathrm{H}-5), 7.89(1 \mathrm{H}, \mathrm{d}$, $J=15.5 \mathrm{~Hz}, \mathrm{H}-4)$, an olefinic proton at $\delta_{\mathrm{H}} 5.85(1 \mathrm{H}, \mathrm{s}, \mathrm{H}-2)$, and three tertiary methyl groups at $\delta_{\mathrm{H}} 0.94\left(3 \mathrm{H}, \mathrm{br} \mathrm{s}, \mathrm{H}-8^{\prime}\right)$, $1.17\left(3 \mathrm{H}\right.$, br s, $\left.\mathrm{H}-7^{\prime}\right), 2.02(3 \mathrm{H}$, br s, H-6). A $\beta$-anomeric proton of a sugar moiety was appeared at $\delta_{\mathrm{H}} 4.38(1 \mathrm{H}, \mathrm{d}$, $\left.J=8.0 \mathrm{~Hz}, \mathrm{H}-1^{1 \prime}\right)$. The ${ }^{13} \mathrm{C}-\mathrm{NMR}$ and HSQC spectra (Figures S3 and S4) of $\mathbf{1}$ indicated the presence of 21 signals including three methyl, four methylene, nine methine, and five quaternary carbon groups. A glucopyranose was recognized by six characteristic signals at $\delta_{\mathrm{C}} 103.1\left(\mathrm{C}-1^{\prime \prime}\right), 75.1$ $\left(\mathrm{C}-2^{\prime \prime}\right), 78.0\left(\mathrm{C}-3^{\prime \prime}\right), 71.6\left(\mathrm{C}-4^{\prime \prime}\right), 77.9\left(\mathrm{C}-5^{\prime \prime}\right)$, and $62.7(\mathrm{C}-$ $\left.6^{\prime \prime}\right)$. Acid hydrolysis followed by HPLC analysis allowed confirming the $D$-glucose. The remaining 15 carbon signals suggested the presence of a megastigmane structure. The positions of the two double bonds at C-7 and C-9 were assigned by HMBC (Figure S5), correlations of $\mathrm{H}-10$ to $\mathrm{C}-8$, C-9, and the carboxyl group, H-7 to C-6, C-8, and C-9, and
TABLE 1: Inhibitory activity of NO production of compounds 1-4.

\begin{tabular}{lc}
\hline Compounds & $\mathrm{IC}_{50}$ in $\mu \mathrm{M}$ \\
\hline Gangeticoside (1) & $22.3 \pm 3.06$ \\
Leonuriside A (2) & $15.6 \pm 2.45$ \\
Methyl benzoate 2-O- $\beta$-D-glucopyranoside (3) & $7.3 \pm 1.27$ \\
Tortoside A (4) & $>30$ \\
Cardamonin (positive control) & $2.72 \pm 0.13$ \\
\hline
\end{tabular}

H-8 to C-6, C-7, C-9, and C-10. The position of glucose was elucidated by the correlation between $\mathrm{H}-1^{\prime}$ and $\mathrm{C}-3$. The positions of three methyls were assigned by HMBC correlations between $\mathrm{H}-11$ to $\mathrm{C}-1, \mathrm{H}-13$ to $\mathrm{C}-5$, and $\mathrm{H}-14$ to C-9 (Figure 2). The compound 1 showed similar structural properties to dihydrophaseic acid, the other megastigmane in the previous study [11]. However, the presence of the quaternary carbon $\mathrm{C}-1$ and the $\mathrm{HMBC}$ correlation between $\mathrm{H}-12$ to the carboxyl group revealed the structure of a lactone, rather than a carboxylic acid. As can be seen from Figure 2, the NOE correlation between $\mathrm{H}-7 / \mathrm{H}-12$ and no correlation between $\mathrm{H}-7 / \mathrm{H}-8$ indicated $\mathrm{E}$ geometry of the double bond at C-7, whereas the correlation between $\mathrm{H}-10$ / H-14 suggested Z-geometry of C-9 double bond (Figure S6). Based on the above analysis, the structure of compound 1 was elucidated as a new megastigmane glycoside, which was named gangeticoside.

Three known compounds were elucidated by comparing their NMR data to the previous reports, including leonuriside A (2) [12], methyl benzoate 2 -O- $\beta$-D-glucopyranoside (3) [13], and tortoside A (4) [14]. Compounds 1, 2, and 3 exhibited significant anti-inflammatory activity with $\mathrm{NO}$ inhibition $\mathrm{IC}_{50}$ at $22.3,15.6,7.3 \mu \mathrm{M}$, respectively, while compound 4 was inactive (Table 1). The MTT assay showed that those compounds had no significant toxicity to RAW264.7 cells up to $50 \mu \mathrm{M}$ (data not shown), indicating that the inhibitory effect on NO production was not due to cytotoxicity.

It is reported that the extracts of Desmodium gangeticum exhibited significant anti-inflammatory effect in vitro as well as in animal models $[15,16]$. Among phytochemical constituents isolated from D. gangeticum, 
(17Z,20Z)-hexacosa-17, 20-dien-9-one and gangenoid dose-dependently inhibited proinflammatory cytokines TNF- $\alpha$ and IL-6 in LPS-stimulated RAW264.7 cells [17]. The pterocarpenoid gangetin exhibited potent anti-inflammatory properties against the carrageenininduced paw edema in rats [18]. Consistently, the present study identified other components in D. gangeticum responsible for the antiinflammation effect of this plant.

\section{Conclusions}

In conclusion, a new megastigmane glycoside, gangeticoside (1), and three known compounds leonuriside A (2), methyl benzoate 2-O- $\beta$-D-glucopyranoside (3), and tortoside A (4) were isolated from the aerial part of Desmodium gangeticum. Compounds 1, 2, and 3 exhibited strong effect on $\mathrm{NO}$ production in LPS-stimulated RAW264.7 cells with the $\mathrm{IC}_{50}$ values of $22.3,15.6$, and $7.3 \mu \mathrm{M}$, respectively.

\section{Data Availability}

The data used in the study are available from the corresponding author upon request.

\section{Conflicts of Interest}

The authors declare that there are no conflicts of interest regarding the publication of this paper.

\section{Acknowledgments}

This work was supported by a grant from the National Foundation for Science and Technology Development (grant code 106-YS.05-2016.02).

\section{Supplementary Materials}

HR-ESI-MS and NMR spectra of compound 1. Figure S1: HR-ESI-MS spectrum of 1. Figure S2: ${ }^{1} \mathrm{H}$ NMR spectrum of 1. Figure S3: ${ }^{13} \mathrm{C}$ NMR spectrum of 1. Figure S4: HSQC spectrum of 1. Figure S5: HMBC spectrum of 1. Figure S6: NOESY spectrum of 1. (Supplementary Materials)

\section{References}

[1] V. V. Chi, Dictionary of Vietnamese Medicinal Plants, Medical Publisher, Hanoi, Vietnam, 2012.

[2] S. Suman, P. Neha, and P. Bhupesh, "A review on Shalparni (Desmodium gangeticum DC.) and Desmodium species (Desmodium triflorum DC. \& Desmodium laxiflorum DC.) Ethnomedicinal perspectives," Journal of Medicinal Plants Studies, vol. 3, no. 4, pp. 38-43, 2015.

[3] L. M. Ha, N. T. Luyen, N. T. Phuong et al., "Isoflavonoids from Desmodium heterophyllum aerial parts," Natural Product Communications, vol. 13, no. 6, pp. 699-700, 2018.

[4] R. Govindarajan, H. Asare-Anane, S. Persaud, P. Jones, and P. Houghton, "Effect of Desmodium gangeticum extract on blood glucose in rats and on insulin secretion in vitro," Planta Medica, vol. 73, no. 5, pp. 427-432, 2007.

[5] X. Ma, C. Zheng, C. Hu, K. Rahman, and L. Qin, "The genus Desmodium (Fabaceae)-traditional uses in Chinese medicine, phytochemistry and pharmacology," Journal of Ethnopharmacology, vol. 138, no. 2, pp. 314-332, 2011.

[6] S. Rastogi, M. M. Pandey, and A. K. S. Rawat, "An ethnomedicinal, phytochemical and pharmacological profile of Desmodium gangeticum (L.) DC. and Desmodium adscendens (Sw.) DC," Journal of Ethnopharmacology, vol. 136, no. 2, pp. 283-296, 2011.

[7] R. Korhonen, A. Lahti, H. Kankaanranta, and E. Moilanen, "Nitric oxide production and signaling in inflammation," Current Drug Target -Inflammation \& Allergy, vol. 4, no. 4, pp. 471-479, 2005.

[8] Y. C. Luiking, M. P. Engelen, and N. E. Deutz, "Regulation of nitric oxide production in health and disease," Current Opinion in Clinical Nutrition and Metabolic Care, vol. 13, no. 1, pp. 97-104, 2010.

[9] W.-J. Jiang, K. i. Ishiuchi, M. Furukawa, T. Takamiya, S. Kitanaka, and H. Iijima, "Stereospecific inhibition of nitric oxide production in macrophage cells by flavanonols: synthesis and the structure-activity relationship," Bioorganic \& Medicinal Chemistry, vol. 23, no. 21, pp. 6922-6929, 2015.

[10] N. M. Chau, H. M. Tuan, T. M. Hung, N. T. Dat, and N. H. Dang, "Anti-inflammatory constituents from Eurycoma longifolia roots," Letters in Organic Chemistry, vol. 17, no. 6, pp. 455-458, 2020.

[11] N. T. T. Ngan, T. H. Quang, S. B. Song, and Y. H. Kim, “Antiinflammatory and PPAR transactivational effects of components from Ginkgo biloba seeds," Bulletin of the Korean Chemical Society, vol. 35, no. 9, pp. 2843-2846, 2014.

[12] H. Otsuka, M. Takeuchi, S. Inoshiri, T. Sato, and K. Yamasaki, "Phenolic compounds from Coix lachryma-jobi var. Mayuen," Phytochemistry, vol. 28, no. 3, pp. 883-886, 1989.

[13] M. Ushiyama and T. Furuya, "Glycosylation of phenolic compounds by root culture of Panax ginseng," Phytochemistry, vol. 28, no. 11, pp. 3009-3013, 1989.

[14] S.-Y. Lyu and W.-B. Park, "Modulation of IL-12 and IFN- $\gamma$ secretions by eleutheroside E, tortoside A, and syringaresinol from acanthopanax koreanum nakai," Biomolecules and Therapeutics, vol. 18, no. 2, pp. 211-218, 2010.

[15] R. Govindarajan, M. Vijayakumar, C. V. Rao et al., "Antiinflammatory and antioxidant activities ofDesmodium gangeticum fractions in carrageenan-induced inflamed rats," Phytotherapy Research, vol. 21, no. 10, pp. 975-979, 2007.

[16] A. Rathi, C. V. Rao, B. Ravishankar, S. De, and S. Mehrotra, "Anti-inflammatory and anti-nociceptive activity of the water decoction Desmodium gangeticum," Journal of Ethnopharmacology, vol. 95, no. 2-3, pp. 259-263, 2004.

[17] A. K. Yadav, J. Agrawal, A. Pal, and M. M. Gupta, "Novel antiinflammatory phytoconstituents from Desmodium gangeticum," Natural Product Research, vol. 27, no. 18, pp. 1639-1645, 2013.

[18] D. Ghosh and A. Anandakumar, "Anti-inflammation and analgesic activity of Gangetin-a pterocarpenoid from Desmodium gangeticum DC," Indian Journal of Pharmacology, vol. 15, pp. 391-402, 1983. 